\title{
The Role of Open-ended Tasks in the Development of Student Activities and Creative Thinking
}

\author{
Dragana Savić \\ Primary School Kneginja Milica
}

\section{Abstract}

This research deals with open-ended tasks whose importance is reflected in them enabling different approaches to reaching various possible solutions appropriate for different levels of student understanding. The basic importance of these tasks lies in the fact they can be used to learn different strategies, deepen students' mathematical knowledge and develop their creative mathematical thinking. The approach to solving open-ended tasks is a step closer to connecting students' mathematical literacy and real-life situations.

This paper aims to investigate the effects of open-ended tasks in teaching mathematics on the outcome of learning mathematics and the opinion of students and teachers about it. By comparing the students' answers, no statistically significant difference was found between the test results of the experimental group solving open-ended tasks and the control group in which students solved closed tasks. This is justified by greater experience that the students have gained in solving closed tasks. By analysing the activity in solving the tasks, a statistically significant difference between the experimental group and the control group was found.

Keywords: class activity; communication; levels of student knowledge; open-ended and closed tasks.

\section{Introduction}

Since mathematical research is nothing but a daily confrontation with open-ended problems, the introduction of this type of problems to the classroom brings mathematical education one step closer to real mathematics (Wu, 1994, p.1).

Open problems can embed students' idea that understanding and explanation are equally important aspects of mathematics ... One of the benefits of resolving open- 
ended problems is breaking of stereotypes that there is only one way to solve problems in mathematics, and that this method is given by teachers (YEO, 2009).

The effectiveness of open-ended tasks can be considered by analysing student responses to one pair of contents of open-ended and closed tasks (Al-Absi, 2013; WhiteWhite et al., 2016).

It is not necessary to evaluate all open-ended tasks for solving the problem formally. The ways of assessing students on these tasks depends on the type of information that the teacher needs. The open nature of the problem solving questions requires more communication among members to devise mathematical ideas in relation to the problem (Chan, 2005; Sullivan et al, 2000).

In the process of mathematical education, numerous examples show that students will fully develop their own creative potentials if the instruction is led by a creative teacher who is in daily contact with his/her students. Maths teaching and other forms of mathematical education in which a creative teacher and a potentially creative student cooperate is the ideal combination for developing students' creative thinking (Spijunovic, 2005, p.161).

In accordance with the stated research objective, I start from the hypotheses:

H1: There is a statistically significant difference between students' achievements on the mathematical test in the experimental and control group.

$\mathrm{H} 2$ : There is a statistically significant difference between the experimental and control group with regards to student engagement in a group as a team.

Open-ended tasks are in the focus of this research work. They allow diverse access, solving tasks with more precise answers and involving students in formulating new tasks themselves. Teachers can convert closed tasks found in textbooks to open-ended tasks (Foong, 2002).

The paper presents the situation as an open process through the solving of openended tasks. There are no known outcomes at the beginning. Students are given the freedom to solve tasks, which means they can have different, equally accurate, solutions. It provides an opportunity for students to offer solutions that correspond to their level of understanding; some will be satisfied with a single solution, some will find multiple solutions or all if possible. Students formulate questions and explore different possibilities by deepening mathematical thinking (developing creative thinking). Teachers can recognize solutions that are the result of deeper thinking.

\section{Methods}

In this paper, experimental and descriptive research methods were applied through observation, surveying, testing and content analysis techniques. The SPSS statistical package was used for data processing. Before conducting this research, a consent was obtained from schools, teachers and students. Experimental research was conducted on the sample of fifth grade students from two primary schools in New Belgrade. All five fifth grade classes from Primary School Kneginja Milica (127 students), and five 
classes (out of the existing six), that is, 122 students from Primary School 20 October participated in the experiment. The experiment began with the initial equivalence of schools (their location, the size of the school's surrounding area, the teaching staff's composition). Students of each class are divided into six equal groups (on the basis of previous knowledge and students' mental abilities variables). In the Achievement test, the first three groups solved open-type tasks and the other three groups closed-type tasks. Students win a point for each task done correctly. The research process involved six teachers and a researcher who attended each lesson. The research was conducted from mid-May to early June 2018.

The description of the research entails examining fifth grade students from ten classes of the mentioned schools through the test of achievement in solving open and closed type tasks, observing students and monitoring their activities. The activities of the experimental and control group are evaluated through variables of negotiation and discussion about the solutions (on a scale of $0-1$ ), and the time of engagement on the tasks (on a scale of 0-6). Testing instruments, teacher schedules and survey sheets were used as the instrument of description. In the final part of the lesson, a survey among the students of the experimental group was conducted and compiled. In such a way, they expressed their opinion about the implemented class, their own activities, communication with other members of the group, and progress in knowledge. The survey showed group work's representation in previous teaching. The application of the descriptive method, with the appropriate statistical data processing, enables the implementation of causal conclusions about the effects of applying open-type tasks in the teaching of mathematics to learning outcomes and the development of their creative thinking. The sample was selected randomly from two primary schools, from the total of 19 primary schools in the territory of the New Belgrade Municipality. Considering the number of students in the sample (249), it is a large sample that allows a more precise assessment. However, observation of the sample requires more time. After selecting the sample, the data was collected and processed statistically. Appropriate statistical procedures were used to validate the generalisation.

\section{Results}

The research process started by dividing students into six equal groups, with the help of their math teachers. Tests with open-ended tasks and tests with closed tasks contained ten tasks (Appendix). Six open-ended tasks were taken from a textbook with a workbook for the fifth grade of elementary school (2018), by authors I. Anic, R. Kosanin and A. Ravas; with four authoritative tasks. Students were given only brief instructions related to the mode of work and they were allowed to communicate within the group. This part of the lesson lasted five minutes. The teacher observed and recorded the characteristic activities of each group and recorded the sequence of group work submissions. Students solved tasks and the teacher only guided and directed them, not speaking about the accuracy of the solution. Task solving lasted 
thirty-five minutes. After that, students filled out a survey previously compiled by researchers. In this way, the students assessed their own activities in the new teaching situation as they perceived them.

This part of the paper presents the characteristic solutions of all open-ended tasks and their analysis. The content of the survey is presented in Table 1.

Table 1

Survey

Answer the first four questions with a mark from 5 (maximum) to 1 (minimum), or yes or no to the fifth question.

\begin{tabular}{|c|c|c|c|c|c|}
\hline Questions: & \multicolumn{5}{|c|}{ Answer } \\
\hline 1 How interesting was the class? & 1 & 2 & 3 & 4 & 5 \\
\hline $\begin{array}{l}2 \text { How would you assess your communication with other members } \\
\text { of the group? }\end{array}$ & 1 & 2 & 3 & 4 & 5 \\
\hline 3 How would you assess your activity in tasks solving? & 1 & 2 & 3 & 4 & 5 \\
\hline 4 How much have you progressed in knowledge? & 1 & 2 & 3 & 4 & 5 \\
\hline 5 Do you often work in a group in mathematics classes? & \multicolumn{3}{|c|}{ Yes } & \multicolumn{2}{|c|}{ No } \\
\hline
\end{tabular}

\section{Solutions of open-ended tasks by students}

\section{1}

$1800,9000,1008,9990,9900,3330,1332,2322,3222,9756,2232,1818,1530,6642,9144,6966$, $4500,3600,3330$

\section{2}

$\frac{480}{100}, \frac{490}{100}, \frac{500}{100}, \frac{600}{100}, \frac{680}{100}$

5,$2 ; 6,3 ; 7,4 ; 8,3 ; 9,6$

4,$71 ; 4,72 ; 4,73 ; 4,75 ; 4,74$

4,$8 ; 5,7 ; 11,9 ; 22,9 ; 21,9$

$7,9,11,23,86$

$10,11,12,13,14$

$5,6,7,8,9$

3

$12,10,10,20 ; 14,11,15,12 ; 20,20,8,4 ; 20,14,15,3 ; 20,11,8,13 ; 40,9,1,2$;

$12,10,8,22$;

4

$\frac{5}{6} \cdot \frac{6}{5} ; \frac{3}{4} \cdot \frac{4}{3} ; \frac{7}{8} \cdot \frac{8}{7} ; \frac{5}{7} \cdot \frac{7}{5} ; \frac{2}{5} \cdot \frac{5}{2}$

5

Which number should be added to number 36,5 to get number 38,1 ?

Sonja has a few euros and Anja has 36,5 euros. How much does Sonja have if they have a total of 38,1 euros?

Nina poured a few litres of water in a bucket. She poured more $36,5 l$. How many litres did she pour if there was a total of $38,1 l$ in the bucket? 
Milan imagined a number. Peter added 36,5 to this number. The sum of these two numbers is 38,1 . What number did Milan imagine?

Jadranka is $36,5 \mathrm{~kg}$ heavy. The average weight of children at her age is $38,1 \mathrm{~kg}$. How much weight does she need to gain to have average weight?

Vanja went to the shop. She bought fruit and vegetables. She paid 36,5 dinars for the fruit and the total amount was 38,1 dinars. How much did Vanja pay for the vegetables?

One man bought $36,5 \mathrm{~kg}$ strawberries. He got a bonus, but he is not sure how much it is; he only knows that it was $38,1 \mathrm{~kg}$ overall. Calculate how many kilograms of strawberries he got?

6

144,$120 ; 240,264 ; 240,888 ; 168,216$

7

3,$61 ; 3,62 ; 3,63$

3,$56 ; 3,59 ; 3,57$

3,$57825 ; 3,5826 ; 3,5648$

8

$(1+1) \cdot 1-(1-1)$

$7 \cdot 5+3+9+6+7: 7+6+9$

$\left(1-\frac{3}{5}\right) \cdot \frac{4}{7}$

$\left(\frac{1}{2}+\frac{3}{4}\right) \cdot 2 \frac{3}{5}$

$\left(\frac{3}{7}+5 \frac{2}{7}\right): \frac{2}{3}$

$342-200$

$\left(\frac{6}{8} \cdot \frac{3}{4}\right)+\left(\frac{7}{2}: \frac{4}{3}\right)$

$\frac{8}{5} \cdot \frac{5}{16}+\frac{7}{8}+\frac{2}{8}$

3.12-18:9

$46 \cdot(13,82-4,81)$

9

311,$120 ; 307,306 ; 647,362 ; 317,300 ; 601,302 ; 607,102 ; 101,100 ; 307,302$;

587,$362 ; 997,922 ; 311,300 ; 349,222$

\section{0}

$A=\{1,5\} B=\{3,7\} ; A=\{1,7\} B=\{3,5\} ; A=\{1,3\} B=\{5,7\} ;$

$A=\{1\} B=\{3,5,7\} ; A=\{1,3,7,5\} B=\{\} ; A=\{\} B=\{1,3,5,7\} ;$

$A=\{3,5,7\} B=\{1\} ; A=\{5,7\} B=\{3,1\} ; A=\{3,5\} B=\{1,7\} ;$

$A=\{1,5,7\} B=\{3\} ; A=\{1,3,7\} B=\{5\} ; A=\{1,3,5\} B=\{7\} ;$

$A=\{7\} B=\{1,3,5\} ; A=\{5\} B=\{1,3,7\}$

\section{Analysis of the results to open-ended tasks}

The survey sample consisted of 127 students of the fifth grade from one school, and 122 students of the fifth grade from the other school, in the school year 2017/2018. The research was carried out at the end of the year, after processing all teaching units. 
On the basis of the given solutions of open-ended tasks, the following is observed: - different solutions,

- different ideas (students use natural numbers, decimal numbers, fractions),

- successful design of tasks in which the connection with the real context is noticed, - giving more solutions by individual groups, although this is not required in the task.

\section{Comparative analysis of the experimental and control group in the achievement test}

Table 2 presents the statistically processed results; the existence of statistical differences amongst them.

Table 2

Descriptive statistics of the experimental and control group in the test of achievement

\begin{tabular}{|c|c|c|c|c|c|c|c|}
\hline Tasks & Group & $N$ & $M$ & $S D$ & t-test & $d f$ & $p$ \\
\hline Task 1 & $\begin{array}{c}\text { Control } \\
\text { Experimental }\end{array}$ & $\begin{array}{l}30 \\
30\end{array}$ & $\begin{array}{l}97 \\
97\end{array}$ & $\begin{array}{l}183 \\
, 183\end{array}$ & ,000 & 58 & 1,000 \\
\hline Task 2 & $\begin{array}{c}\text { Control } \\
\text { Experimental }\end{array}$ & $\begin{array}{l}30 \\
30\end{array}$ & $\begin{array}{l}, 87 \\
, 87\end{array}$ & $\begin{array}{l}, 346 \\
346\end{array}$ & ,000 & 58 & 1,000 \\
\hline Task 3 & $\begin{array}{c}\text { Control } \\
\text { Experimental }\end{array}$ & $\begin{array}{l}30 \\
30\end{array}$ & $\begin{array}{l}, 93 \\
, 80\end{array}$ & $\begin{array}{l}, 254 \\
, 407\end{array}$ & 1,523 & 48,592 & 134 \\
\hline Task 4 & $\begin{array}{c}\text { Control } \\
\text { Experimental }\end{array}$ & $\begin{array}{l}30 \\
30\end{array}$ & $\begin{array}{l}97 \\
, 90\end{array}$ & $\begin{array}{l}183 \\
, 305\end{array}$ & 1,027 & 47,406 & ,310 \\
\hline Task 5 & $\begin{array}{c}\text { Control } \\
\text { Experimental }\end{array}$ & $\begin{array}{l}30 \\
30\end{array}$ & $\begin{array}{l}93 \\
, 97\end{array}$ & $\begin{array}{l}, 254 \\
, 183\end{array}$ &,- 584 & 58 &, 561 \\
\hline Task 6 & $\begin{array}{c}\text { Control } \\
\text { Experimental }\end{array}$ & $\begin{array}{l}30 \\
30\end{array}$ & $\begin{array}{l}, 60 \\
, 40\end{array}$ & $\begin{array}{l}, 498 \\
, 498\end{array}$ & 1,555 & 58 & ,125 \\
\hline Task 7 & $\begin{array}{c}\text { Control } \\
\text { Experimental }\end{array}$ & $\begin{array}{l}30 \\
30\end{array}$ & $\begin{array}{l}, 27 \\
, 47\end{array}$ & $\begin{array}{l}, 450 \\
, 507\end{array}$ & $-1,616$ & 57,177 & 112 \\
\hline Task 8 & $\begin{array}{c}\text { Control } \\
\text { Experimental }\end{array}$ & $\begin{array}{l}30 \\
30\end{array}$ & $\begin{array}{l}, 80 \\
, 93\end{array}$ & $\begin{array}{l}, 407 \\
, 254\end{array}$ & $-1,523$ & 48,592 & ,134 \\
\hline Task 9 & $\begin{array}{c}\text { Control } \\
\text { Experimental }\end{array}$ & $\begin{array}{l}30 \\
30\end{array}$ & $\begin{array}{l}77 \\
, 70\end{array}$ & $\begin{array}{l}, 430 \\
, 466\end{array}$ & ,576 & 58 &, 567 \\
\hline $\begin{array}{c}\text { Task } \\
10\end{array}$ & $\begin{array}{c}\text { Control } \\
\text { Experimental }\end{array}$ & $\begin{array}{l}30 \\
30\end{array}$ & $\begin{array}{l}, 93 \\
, 83\end{array}$ & $\begin{array}{l}254 \\
, 379\end{array}$ & 1,201 & 50,641 & 235 \\
\hline
\end{tabular}

\section{Observations of the teachers about student activities in the class}

The implementation of the research was carried out by a descriptive method or by teachers observing student activities in groups that solved open-ended tasks and groups that solved closed tasks. These observations about students' activities are systematized as follows:

- Working in groups, regardless of the type of tasks they have solved, has created mutual student collaboration, negotiation, division of work, discussion of solutions, guidance by an individual, checking; 
- Communication existed in all groups, but it was much wider in groups where open-ended tasks were tackled;

- In groups with open-ended tasks, students did not ask for final solutions but were interested in writing more solutions (their conclusion is that the task has more than one solution);

- In groups that solved open-ended tasks, the most common question related to the fifth task of whether, in addition to formulating the text, the equation also needed to be solved. Student responses contained formulations placed in the real life and time context (some of these characteristic responses are highlighted);

- Students who did closed tasks generally did them individually, and then checked each other's solutions before writing them to a group board after a discussion. Students who did open-ended tasks did them in order and discussed how to get a solution before they wrote down the final solutions on the board. The frequent questions raised by these students regarding the first task was whether to indicate only one or more four-digit even numbers dividable by 9 . One of the students asked if the word smallest was missing in the task setting (four-digit even number), which indicates that students are accustomed to solving tasks that have one solution (closed tasks). For the tenth assignment, students often asked if they had to provide all the solutions;

- Finding more solutions to the same task suggests that a student develops the ability to switch from one to the other flow of thinking and thus develop the creativity of thinking, that is, the creative thinking as a whole. It is possible to get to know higher or lower levels of understanding by students;

- The time in which the closed tasks were solved was shorter than the time for solving open-ended tasks.

The teachers carefully recorded the activities of each group in the notebook, with special emphasis on negotiating and discussing solutions, as well as their time engagement in the class. The scale for each group was evaluated from 0-1 (negotiation and discussion) and 0-6 (time of engagement on the tasks) and it was written down on the questionnaire. Using the t-test, it is determined whether these differences are statistically significant.

\section{Comparative analysis of the experimental and control group in activities 1 and 2 in the teacher survey}

Results of the teacher survey are statistically completed and presented in Table 3 and Table 4. It was determined if there is a statistically significant difference between the experimental group and the control group. 
Table 3

Descriptive statistics of the experimental and control group on the activity (negotiation and discussion of the solution) in the teachers' survey

\begin{tabular}{llcccccc}
\hline & Group & $N$ & $M$ & $S D$ & $t$-test & $d f$ & $p$ \\
\hline \multirow{2}{*}{ Activity (1) } & Control & 30 &, 43 &, 504 & & & \\
& Experimental & 30 &, 70 &, 466 & $-2,128$ & 58 & \multirow{2}{*}{038} \\
\hline
\end{tabular}

Table 4

Descriptive statistics of the experimental and control group on activity (time of engagement on tasks) in the teachers'survey

\begin{tabular}{llcccccc}
\hline & Group & $N$ & $M$ & $S D$ & t-test & $d f$ & $p$ \\
\hline \multirow{2}{*}{ Activity (2) } & Control & 27 & 2,85 & 1,657 & \multirow{2}{*}{2,958} & \multirow{2}{*}{52} & \multirow{2}{*}{005} \\
& Experimental & 27 & 4,15 & 1,562 & & & \\
\hline
\end{tabular}

Note: One class of the fifth grade is excluded from the statistical data processing in Table 4.

\section{Opinion of the students from the experimental group about the held lesson and their own activities}

Table 5

Survey results

\begin{tabular}{lcc}
\hline Questions: & Mean & Percentage \\
\hline 1 How interesting was the class? & 3,93 & $78,6 \%$ \\
2 How would you assess your communication with other & 4,20 & $84 \%$ \\
$\quad$ members of the group? & 3,99 & $79,8 \%$ \\
3 How would you assess your activity in the tasks solving? & 3,54 & $70,8 \%$ \\
4 How much have you progressed in knowledge? & & $6 \% \quad 94 \%$ \\
5 Do you often work in a group in mathematics classes? & & \\
\hline
\end{tabular}

\section{Discussion}

From Table 2, it can be observed that the mean achievement values in the experimental group test in relation to the control group are higher in tasks 5, 7 and 8 . We will examine whether these differences are statistically significant (applied t-test) in these and other tasks.

The results in Table 2 show that there is no statistically significant difference in the achievements of the experimental and control group on the tasks, with a reliability of $95 \%$. Therefore, the hypothesis $\mathrm{H}_{1}$ is not confirmed in the work. The results of the research can nevertheless be considered valuable because the students of this sample did not have a similar type of requirements and experience in solving the tasks of this type in the previous classes. The researcher is of the opinion that open-ended tasks should be introduced into the teaching process because student responses show solving these tasks develops creative thinking. This opinion is supported by teachers whose enhanced experiences help them in harmonising students' creative thinking on the one hand and evaluate them within curricula on the other hand. New techniques and tools are important for determining the learning outcomes. 
The results in Table 3 and Table 4 show, with the reliability of 95\%, that there is a statistically significant difference in the activities between the experimental and the control group. This confirmed the $\mathrm{H}_{2}$ hypothesis in the work.

Generally, the use of open-ended tasks in learning mathematics positively affects students' opinions about a new teaching situation, in which they assess their own communication, activity and progress, with a high grade. The survey clearly shows that there was little group work used in maths lessons in previous work. This can be seen in the Table 5.

\section{Conclusion}

The application of open-ended tasks in mathematics aims to develop creative mathematical thinking so that a student in mathematics not only provides one, but more solutions that come in different ways. Research is important to assist teachers in introducing this approach to supporting students in developing their creative potential through learning mathematics. Of course, this also requires the teacher to further engage in the selection of tasks and methods of evaluation.

The first part of the research findings in this paper shows no statistically significant difference in the test results of the experimental group, that solved the open-ended tasks, and the control group, that solved the closed tasks. Students who solved closed tasks have become accustomed to this kind of work, or had had more experience. The analysis of student responses in the experimental group showed more solutions and creativity in their thinking, corresponding to the levels of their understanding. The researcher is of the opinion that gradual introduction of open-ended tasks would result in improved effects on test achievements in the long run. In the beginning, it would certainly be a combination of open and closed type tasks.

The second part of the study's findings shows a statistically significant difference in the activities of the experimental group in relation to the control group. Namely, the negotiation and discussion of the solution are used as activity variables, as well as the time of engagement in solving the tasks. They are taken from the systematized records of teachers. Students using open-ended tasks can be more successful in all these aspects.

A survey conducted in the experimental group shows that the use of open-ended tasks has a positive impact on the students' impressions about the lecture held and their own activities, which can be reflected in their self-confidence in the work.

\section{References:}

Al-Absi, M. (2013).The Effect of Open-ended Tasks -as an assessment tool- on Fourth Graders' Mathematics Achievement, and Assessing Students 'Perspectives about it. Jordan Journal of Educational Sciences, 9(3), 345-351.

Anic, I., Kosanin, R., \& Ravas, A. (2018). Mathematics, Textbook and Task Collection for Fifth grade, Elementary school Bigz education. 
Chan, C. M. E. (2007). Using Open-Ended Mathematics Problems A Classroom Experience (Primary). In C. Shegar, \& R. B. A. Rahim (Eds.), Redesigning pedagogy: Voices of Practitioners (pp. 129-146). Pearson Education South Asia. http://citeseerx.ist.psu.edu/viewdoc/ download?doi $=10.1 \cdot 1.522 .9901 \& \mathrm{rep}=$ rep 1 \&type $=$ pdf

Foong, P.Y. (2002). Using Short Open - ended Mathematics Questions to Promote Thinking and Understanding. In A. Rogerson (Ed.), Proceedings of the International Conference: The Humanistic Renaissance in Mathematics Education (pp.135-140). http://math.unipa. it/ grim/SiFoong.PDF

Spijunovic, K. (2005). Creative thinking and mathematical education. Teacher training Faculty.

Sullivan, P., Warren, E., \& White, P. (2000).Students' Responses to Content Specific Open Ended Mathematical Tasks.Mathematics Education Research Journal,12(1), 2-17. https:// doi.org/10.1007/BF03217071

Wu, H.(1994).The Role of Open-ended Problems in Mathematics Education. The Journal of Mathematical Behavior, 13(1), 115-128.

White, P., Sullivan, P., Warren, E., \& Quinlan, C. (2016).To investigate or not to investigate?The use of content specific open-ended tasks. Australian Mathematics Teacher, 72(3), 61-64.

Yeo, K. K. J. (2009). Integrating Open-Ended Problems in the Lower Secondary Mathematics Lesssons. In B. Kauar, B.H. Yeap, \& M. Kapur (Ed.), Mathematical Problem solving (pp.226239). National Institute of Education. https://doi.org/10.1142/9789814277228_0012

\section{Dragana Savić}

Primary School Kneginja Milica

Jurija Gagarina 78, 11000 Belgrade, Serbia

gagasavic89@gmail.com 


\section{Appendix \\ Tests with tasks}

Open-ended tasks

1 Write a four-digit even number dividable by 9 .

2 Specify five numbers that satisfy the inequation $x-1,21>3,49$.

3 Write four numbers whose arithmetic mean is $\mathbf{1 3}$.

4 Write two fractions whose product equals 1.

5 Think of the text of the problem solved by the equation $x+36,5=38,1$.

6 Write two three-digit numbers if the greatest common divisor is number 24.

7 Write three decimal numbers so that, when we round them to one decimal, we get number 3,6.

8 Compose a numerical expression and calculate its numerical value.

9 Write two three-digit numbers, one prime and the other composite, so that the prime number is larger than the composite number.

10 Define sets $\boldsymbol{A}$ and $\boldsymbol{B}$ so that $\boldsymbol{A} \cup \boldsymbol{B}=\left\{\mathbf{1}, 3,5,{ }^{7}\right\}$ and $\boldsymbol{A} \cap \boldsymbol{B}=\emptyset$.

\section{Closed tasks}

1 Is the number 1521 dividable by 9 ?

2 Solve the inequation:

$\mathrm{x}-1,21>3,49$.

3 Calculate the arithmetic mean of the numbers 12, 15, 14 and 11.

4 Calculate: $3 \frac{2}{5} \cdot \frac{5}{17}$.

5 What number should be increased by 36,5 to get number 38,1 ?

6 Determine the greatest common divisor of numbers 840 and 936 .

7 Round the numbers 3,$55 ; 3,632$ and 3,5665 to one decimal.

8 Calculate the value of the expression:

$(777-77: 7) \cdot 7+77$

9 Are the numbers 113 and 325 prime?

10 The sets $\boldsymbol{A}=\{\mathbf{1}, \mathbf{3}, \mathbf{5}, 7\}$ and $\boldsymbol{B}=\{\mathbf{2}, \mathbf{4}, \mathbf{6}\}$ are given. Define sets: a) $\boldsymbol{A} \cup \boldsymbol{B}$; b) $\boldsymbol{A} \cap \boldsymbol{B}$. 


\section{Uloga zadataka otvorenoga tipa u razvoju aktivnosti i kreativnoga mišljenja učenika}

\section{Sažetak}

U fokusu ovoga istraživanja su zadatci otvorenoga tipa. Njihova je važnost vidliva u tome što omogućuju različite postupke dolaska do višestrukih mogućih rješenja primjerenih za različite razine razumijevanja učenika. Osnovni smisao tih zadataka je mogućnost njihova korištenja za učenje različitih strategija, produbljivanje učeničkoga znanja matematike i razvijanje kreativnoga matematičkog mišljenja. Pristup rješavanju zadataka otvorenoga tipa predstavlja korak bliže povezivanju matematičke pismenosti učenika i stvarnih životnih situacija.

Cilj je ovoga rada istražiti učinke zadataka otvorenoga tipa u poučavanju matematike na ishode učenja matematike i mišljenje učenika i učitelja o njima. Usporedba učeničkih odgovora nije pokazala statistički značajnu razliku između rezultata testa eksperimentalne skupine, koja je rješavala zadatke otvorenoga tipa, i kontrolne skupine, u kojoj su učenici rješavali zadatke zatvorenoga tipa. Veće iskustvo koje su učenici stekli rješavajući zadatke zatvorenoga tipa objašnjava navedeni rezultat. Analiza aktivnosti u rješavanju zadataka ukazuje na statistički značajnu razliku između eksperimentalne $i$ kontrolne skupine.

Ključne riječi: komunikacija; razine znanja učenika; razredna aktivnost; zadatci otvorenoga i zatvorenoga tipa.

\section{Uvod}

Budući da matematičko istraživanje u stvari predstavlja dnevno suočavanje s problemima otvorenoga tipa, uvođenje ove vrste problema u učionicu dovodi matematičko obrazovanje korak bliže stvarnoj matematici (Wu, 1994, str.1).

Otvoreni problemi mogu obogatiti učeničko poimanje razumijevanja i objašnjenja kao jednako važnih aspekata matematike. Jedna od koristi rješavanja problema otvorenoga tipa je rušenje stereotipa koji govori o samo jednom načinu rješavanja problema $u$ matematici, onom koji daju učitelji (YEO, 2009).

Učinkovitost zadataka otvorenoga tipa može se razmotriti analizirajući učeničke odgovore na sadržaje otvorenih i zatvorenih zadataka (Al-Absi, 2013; White, P., Sullivan, P., Warren, E. i Quinlan, C., 2016). 
Nije nužno evaluirati sve zadatke otvorenoag tipa za formalno rješavanje problema. Način evaluacije učenika u tim zadatcima ovisi o vrsti informacije koju treba učitelj. Otvorena priroda pitanja rješavanja problema zahtijeva veću komunikaciju između članova kako bi se osmislile matematičke ideje vezane za problem (Chan, 2005; Sullivan, P., Warren, E. i White, P., 2000).

U procesu matematičkoga obrazovanja, brojni primjeri pokazuju da će učenici u potpunosti razviti svoje vlastite kreativne potencijale ako ih poučava kreativan učitelj koji je u svakodnevnom kontaktu sa svojim učenicima. Poučavanje matematike i drugi oblici matematičkoga obrazovanja u kojima kreativan učitelj i potencijalno kreativan učenik stvaraju se idealne kombinacije za razvijanje kreativnoga mišljenja učenika (Špijunović, 2005, str.161).

Sukladno predstavljenom cilju istraživanja, polazi se od sljedećih hipoteza:

H1: postignuća učenika iz testa matematike u eksperimentalnoj i kontrolnoj skupini statistički su značajno različita.

H2: angažman učenika kao tima u eksperimentalnoj i kontrolnoj skupini statistički je značajno različit.

Zadatci otvorenoga tipa su u fokusu ovoga istraživačkog rada. Oni pružaju prilike za raznolike pristupe, rješavanje zadatka s preciznijim odgovorima i uključivanje učenika u samostalno formuliranje novih zadataka. Učitelji mogu preoblikovati zadatke zatvorenoga tipa iz udžbenika u zadatke otvorenoga tipa (Foong, 2002).

U ovome radu prikazuje se situacija otvorenoga procesa rješavanja zadataka otvorenoga tipa. Na početku nema poznatih ishoda. Učenici imaju slobodu u rješavanju zadatka, što znači da mogu imati različita, jednako točna, rješenja. Imaju priliku ponuditi rješenja sukladna njihovim razinama razumijevanja; neki će biti zadovoljni jednim rješenjem, a neki će pronaći višestruka ili sva moguća rješenja. Učenici formuliraju pitanja i istražuju različite mogućnosti produbljujući matematičko mišljenje (razvijanje kreativnoga mišljenja). Učitelji prepoznaju rješenja koja su rezultat dubljega razmišljanja.

\section{Metode}

U ovome radu primijenjene su deskriptivne i eksperimentalne istraživačke metode promatranja, anketiranja, testiranja i tehnika analize sadržaja. Statistički paket SPSS korišten je za obradu podataka. Prije provođenja istraživanja, dobiven je pristanak škola, učitelja i učenika. Eksperimentalno istraživanje provedeno je na uzorku učenika petih razreda iz dvije osnovne škole u Novom Beogradu. Svih pet petih razreda iz osnovne škole Kneginja Milica, tj. 127 učenika, i pet razreda (od postojećih šest), tj. 122 učenika iz osnovne škole 20. oktobar, sudjelovali su u eksperimentu. Istraživanje je započelo početnim izjednačavanjem škola (njihovih lokacija, veličine područja školske okoline, sastava nastavnoga osoblja). Učenici svakog razreda podijeljeni su u šest jednakih skupina (na osnovi varijabli predznanja i učeničkih mentalnih sposobnosti). U testu postignuća, prve tri skupine rješavale su zadatke otvorenoga tipa, a druge tri skupine zadatke zatvorenoga tipa. Učenici su dobili bod za svaki točno riješen zadatak. Proces 
istraživanja uključivao je šest učitelja i istraživača, koji su bili na svakom nastavnom satu. Istraživanje je provedeno u periodu od sredine svibnja do ranog lipnja 2018. godine.

Istraživanje podrazumijeva ispitivanje učenika deset petih razreda spomenutih škola testom postignuća u rješavanju zadataka otvorenoga i zatvorenoga tipa, promatranje učenika i nadgledanje njihovih aktivnosti. Aktivnosti eksperimentalne i kontrolne skupine evaluirane su kroz varijable pregovaranja i rasprave o rješenjima (na skali od 0 do 1) i angažmana na zadatcima (na skali od 0 do 6). Instrumenti testiranja, učiteljski rasporedi i anketni listići korišteni su kao deskriptivni instrument. U završnom dijelu sata provedena je anketa među učenicima eksperimentalne skupine. Na taj način izrazili su svoje mišljenje o provedenom nastavnom satu, vlastitim aktivnostima, komunikaciji s ostalim članovima skupine i napretku u znanju. Upitnik je dao informaciju i o upotrebi grupnoga rada u prijašnjem poučavanju. Primjena deskriptivne metode, uz odgovarajuću statističku obradu podataka, obogaćuje primjenu kauzalnih zaključaka o učincima primjene zadataka otvorenoga tipa u poučavanju matematike na ishode učenja i razvoj kreativnoga mišljenja učenika. Uzorak je nasumično sastavljen iz dvije osnovne škole na području općine Novi Beograd. Razmatrajući broj učenika u uzorku (249), nameće se zaključak kako je uzorak dovoljno velik da dozvoli preciznije procjene. Ipak, promatranje uzorka zahtijeva više vremena. Nakon odabira uzorka, podatci su sakupljeni i statistički obrađeni. Valjanost generalizacije utvrđena je odgovarajućim statističkim postupcima.

\section{Rezultati}

Proces istraživanja započeo je podjelom učenika u šest jednakih skupina, uz pomoć njihovih učitelja matematike. Testovi sa zadatcima otvorenoga i zatvorenoga tipa sadržavali su deset zadataka (Dodatak). Šest zadataka otvorenoga tipa preuzeti su iz udžbenika s vježbenicom za peti razred osnovne škole (2018), autora I. Anić, R. Kosanin i A. Ravas, s četiri autoritarna zadatka. Učenici su dobili samo kratke upute vezane uz način rada i komunikacije u skupini. Ovaj dio sata trajao je pet minuta. Učitelj je promatrao i bilježio karakteristične aktivnosti svake skupine i slijed predaje rezultata grupnoga rada. Učenici su rješavali zadatke, a učitelji su ih vodili i usmjeravali, ne govoreći o točnosti rješenja. Rješavanje zadataka trajalo je tridesetpet minuta. Ispunjavanje upitnika trajalo je pet minuta. Nakon toga, učenici su ispunjavali upitnik koji su prethodno sastavili istraživači. Procjenjivali su aktivnosti u novoj situaciji poučavanja onako kako su ih doživjeli.

Ovaj dio rada predstavlja karakteristična rješenja svih zadataka otvorenoga tipa i njihove analize. Sadržaj upitnika prikazan je u tablici 1.

Tablica 1.

Upitnik 


\section{Učenička rješenja zadataka otvorenoga tipa}

1.

$1800,9000,1008,9990,9900,3330,1332,2322,3222,9756,2232,1818,1530,6642,9144,6966$,

$4500,3600,3330$

2.

$\frac{480}{100}, \frac{490}{100}, \frac{500}{100}, \frac{600}{100}, \frac{680}{100}$

5,$2 ; 6,3 ; 7,4 ; 8,3 ; 9,6$

4,$71 ; 4,72 ; 4,73 ; 4,75 ; 4,74$

4,$8 ; 5,7 ; 11,9 ; 22,9 ; 21,9$

$7,9,11,23,86$

$10,11,12,13,14$

$5,6,7,8,9$

3.

$12,10,10,20 ; 14,11,15,12 ; 20,20,8,4 ; 20,14,15,3 ; 20,11,8,13 ; 40,9,1,2$;

$12,10,8,22$;

4.

$\frac{5}{6} \cdot \frac{6}{5} ; \frac{3}{4} \cdot \frac{4}{3} ; \frac{7}{8} \cdot \frac{8}{7} ; \frac{5}{7} \cdot \frac{7}{5} ; \frac{2}{5} \cdot \frac{5}{2}$

5.

Koji broj treba dodati broju 36,5 kako bi dobili broj 38,1?

Sonja ima nešto eura, a Anja ima 36,5 eura. Koliko ima Sonja ako zajedno imaju 38,1 eura?

Nina je natočila nekoliko litara vode u kantu. Natočila je više od 36,5 litara. Koliko je litara natočila ako je u kanti ukupno 38,1 litra?

Milan je zamislio broj. Petar je dodao 36,5 tom broju. Suma tih dvaju brojeva je 38,1. Koji broj je Milan zamislio?

Jadranka ima 36,5 kilograma. Prosječna težina djece njezine dobi je 38,1 kg. Koliko kilograma mora dobiti kako bi sustigla prosječnu težinu?

Vanja je otišla u trgovinu. Kupila je voće i povrće. Platila je 36,5 dinara za voće, a ukupni zbroj je 38,1 dinar. Koliko je Vanja platila povrće?

Jedan je čovjek kupio 36,5 kilograma jagoda. Dobio je bonus, ali nije siguran koliki. Samo zna da iznosi 38,1 kg ukupno. Izračunaj koliko je kilograma jagoda dobio?

6.

144,$120 ; 240,264 ; 240,888 ; 168,216$

7.

3,$61 ; 3,62 ; 3,63$

3,$56 ; 3,59 ; 3,57$

3,$57825 ; 3,5826 ; 3,5648$ 
8.

$(1+1) \cdot 1-(1-1)$

$7 \cdot 5+3+9+6+7: 7+6+9$

$(1+1) \cdot 1-(1-1)$

$7 \cdot 5+3+9+6+7: 7+6+9$

$\left(1-\frac{3}{5}\right) \cdot \frac{4}{7}$

$\left(\frac{1}{2}+\frac{3}{4}\right) \cdot 2 \frac{3}{5}$

$\left(\frac{3}{7}+5 \frac{2}{7}\right): \frac{2}{3}$

$342-200$

$\left(\frac{6}{8} \cdot \frac{3}{4}\right)+\left(\frac{7}{2}: \frac{4}{3}\right)$

$\frac{8}{5} \cdot \frac{5}{16}+\frac{7}{8}+\frac{2}{8}$

$3 \cdot 12-18: 9$

$46 \cdot(13,82-4,81)$

9.

311,$120 ; 307,306 ; 647,362 ; 317,300 ; 601,302 ; 607,102 ; 101,100 ; 307,302$;

587,$362 ; 997,922 ; 311,300 ; 349,222$

10

$A=\{1,5\} B=\{3,7\} ; A=\{1,7\} B=\{3,5\} ; A=\{1,3\} B=\{5,7\} ;$

$A=\{1\} B=\{3,5,7\} ; A=\{1,3,7,5\} B=\{\} ; A=\{\} B=\{1,3,5,7\} ;$

$A=\{3,5,7\} B=\{1\} ; A=\{5,7\} B=\{3,1\} ; A=\{3,5\} B=\{1,7\} ;$

$A=\{1,5,7\} B=\{3\} ; A=\{1,3,7\} B=\{5\} ; A=\{1,3,5\} B=\{7\} ;$

$A=\{7\} B=\{1,3,5\} ; A=\{5\} B=\{1,3,7\}$

\section{Analiza rezultata zadataka otvorenoga tipa}

Anketni uzorak uključivao je 127 učenika petih razreda iz jedne škole i 122 učenika petih razreda iz druge škole, u školskoj 2017./2018. godini. Istraživanje je provedeno na kraju godine, nakon obrade svih nastavnih cjelina.

$\mathrm{Na}$ osnovi dobivenih rješenja zadataka otvorenoga tipa, primijećeno je sljedeće:

- različita rješenja

- različite ideje (učenici koriste prirodne brojeve, decimalne brojeve, razlomke)

- primijećeno je uspješno kreiranje zadataka u kojima se pojavljuje veza sa stvarnim životnim kontekstom

- davanje više rješenja individualnih skupina iako se to nije tražilo u zadatku.

\section{Komparativna analiza eksperimentalne i kontrolne skupine u testu postignuća}

Tablica 2 prikazuje statistički obrađene rezultate; postojanje statističkih razlika među njima.

Tablica 2. 


\section{Opservacije učitelja o aktivnostima učenika na nastavnom satu}

Istraživanje je provedeno deskriptivnom metodom ili opservacijama učitelja o aktivnostima učenika u skupinama, pri rješavanju zadataka otvorenoga i zatvorenoga tipa. Opservacije o učeničkim aktivnostima sistematizirane su na sljedeći način:

- rad u grupama, bez obzira na vrstu zadataka koje su rješavali, stvorio je međusobnu učeničku suradnju, pregovaranje, podjelu rada, raspravu o rješenjima, individualno vodstvo, provjeravanje

- komunikacija postoji u svim skupinama, ali je mnogo veća u skupinama koje rješavaju zadatke otvorenoga tipa

- u skupinama sa zadatcima otvorenoga tipa, učenici ne traže konačno rješenje, već žele napisati više rješenja te je njihov zaključak da zadatak ima više od jednog rješenja

- u skupinama koje rješavaju zadatke otvorenoga tipa, većina pitanja odnosi se na peti zadatak, na dodatak formuliranom tekstu, o tome mora li se riješiti i jednadžba. Učenički odgovori sadržavali su formulacije smještene u stvarni životni kontekst (neki od tih karakterističnih odgovora su označeni)

- učenici koji rade zadatke zatvorenoga tipa općenito rješavaju zadatke individualno i mogu međusobno provjeriti rješenja prije nego ih napišu na grupnu ploču nakon rasprave. Učenici koji rješavaju zadatke otvorenoga tipa rade ih redom i raspravljaju o tome kako doći do rješenja prije nego zapišu konačna rješenja na ploču. Česta pitanja koja postavljaju ti učenici vezana su uz prvi zadatak i odnose se na to trebaju li navesti samo jedan ili više četveroznamenkastih brojeva djeljivih s 9. Jedan od učenika pita nedostaje li riječ najmanji u zadatku (parni četveroznamenkasti broj), što ukazuje na to da su učenici navikli rješavati zadatke koji imaju samo jedno rješenje (zatvorenoga tipa); za deseti zadatak, učenici često pitaju moraju li navesti sva rješenja

- nalaženje više rješenja istoga zadatka ukazuje na to da učenik razvija sposobnost prebacivanja iz jednog u drugi tok misli i stoga razvija kreativno mišljenje, tj. kreativno mišljenje kao cjelinu; moguće je da učenici steknu više razine razumijevanja

- vrijeme rješavanja zadataka zatvorenoga tipa je kraće od vremena rješavanja zadataka otvorenog tipa.

Učitelji su pažljivo bilježili aktivnosti svake skupine u svoje bilježnice, s posebnim naglaskom na pregovaranje i raspravu o rješenjima, kao i angažman učenika na satu. Skala procjene svake skupine je od 0 do 1 (pregovaranje i rasprava) te od 0 do 6 (vrijeme rada na zadatcima). Te su vrijednosti upisane u upitnik. Koristeći t-test utvrdili smo jesu li te razlike statistički značajne.

\section{Komparativna analiza eksperimentalne i kontrolne skupine u prvoj i drugoj aktivnosti u anketi s učiteljima}

Rezultati intervjua s učiteljima statistički su obrađeni i predstavljani u tablicama 3 i 4. Istraženo je postojanje statistički značajne razlike između eksperimentalne i kontrolne skupine. 
Tablica 3.

Tablica 4.

\section{Mišljenja učenika eksperimentalne skupine o održanom nastavnom satu i njihovim aktivnostima}

Tablica 5.

\section{Rasprava}

Iz tablice 2 vidljivo je da su vrijednosti aritmetičke sredine postignuća za test eksperimentalne skupine u odnosu na kontrolnu skupinu veće u petom, sedmom i osmom zadatku. Ispitat ćemo jesu li te razlike statistički značajne (primijenjen t-test) u ovim i ostalim zadatcima.

Rezultati u tablici 2 pokazuju da nema statistički značajne razlike u uspjehu eksperimentalne i kontrolne skupine na zadatcima, s pouzdanošću od $95 \%$. Stoga, hipoteza $\mathrm{H}_{1}$ nije potvrđena. Rezultati istraživanja ipak se mogu smatrati vrijednima jer učenici u ovom uzorku nisu imali sličnu vrstu zahtjeva ni iskustava u rješavanju zadataka ove vrste u prijašnjoj nastavi. Istraživač je mišljenja da bi zadatke otvorenoga tipa trebalo uvoditi u proces poučavanja jer učenički odgovori pokazuju da se rješavanjem tih zadataka razvija kreativno mišljenje. U tome ih podržavaju učitelji čije je veće iskustvo bilo od pomoći pri usklađivanju kreativnoga mišljenja učenika, s jedne strane, i njihove evaluacije unutar kurikula, s druge strane. Nove tehnike i alati važni su za utvrđivanje ishoda učenja.

Rezultati u tablicama 3 i 4 pokazuju, uz pouzdanost od $95 \%$, postojanje statistički značajne razlike u aktivnostima između eksperimentalne i kontrolne skupine. Ovime je potvrđena $\mathrm{H}_{2}$ hipoteza.

Općenito, upotreba zadataka otvorenoga tipa u učenju matematike pozitivno utječe na mišljenja učenika o novoj situaciji poučavanja, u kojoj ocjenjuju vlastitu komunikaciju, aktivnosti i napredak visokom ocjenom. Anketa jasno pokazuje da je $\mathrm{u}$ prethodnom periodu poučavanja bilo malo grupnog rada na nastavi matematike. Navedeno je vidljivo iz tablice 5 .

\section{Zaključak}

Primjena zadataka otvorenoga tipa u matematici ima za cilj razvijanje kreativnoga matematičkog mišljenja, kako bi učenici u matematici ponudili ne samo jedno, već više rješenja do kojih su došli na različite načine. Istraživanja su važna kao pomoć učiteljima u uvođenju ovoga pristupa radi podržavanja razvoja učeničkoga kreativnog potencijala kroz učenje matematike. Naravno, ovo također zahtijeva da se učitelji ubuduće više angažiraju u odabiru zadataka i metoda evaluacije.

Prvi dio istraživačkih rezultata u ovom radu pokazuje da nema statistički značajne razlike između rezultata testa eksperimentalne skupine, koja je rješavala zadatke 
otvorenoga tipa i kontrolne skupine, koja je rješavala zadatke zatvorenoga tipa. Učenici koji su rješavali zatvorene zadatke navikli su na tu vrstu rada ili su imali više iskustva. Analiza učeničkih odgovora u eksperimentalnoj skupini pokazala je više rješenja i kreativnosti u njihovu razmišljanju, odgovarajuće njihovim razinama razumijevanja. Istraživač smatra da će dugoročno postupno uvođenje zadataka otvorenoga tipa rezultirati poboljšanim postignućima na testovima. U početku bi to svakako bila kombinacija zadataka otvorenoga i zatvorenoga tipa.

Drugi dio rezultata studije pokazuje postojanje statistički značajne razlike u aktivnostima između eksperimentalne i kontrolne skupine. $U$ tome su korištene varijable aktivnosti pregovaranja i rasprave o rješenjima, kao i vrijeme rada na rješavanju zadataka. One su preuzete iz sustavnih zabilješki učitelja. Učenici koji koriste zadatke otvorenoga tipa mogu biti uspješniji u svim navedenim aspektima.

Anketa provedena u eksperimentalnoj skupini pokazuje da je korištenje zadataka otvorenoga tipa imalo pozitivni učinak na učeničke dojmove o održanom nastavnom satu i njihovim aktivnostima, što se odražava na njihovo samopouzdanje u radu. 